\title{
Effects of anti-vascular endothelial growth factor monoclonal antibody (bevacizumab) on lens epithelial cells
}

This article was published in the following Dove Press journal:

Clinical Ophthalmology

27 June 2016

Number of times this article has been viewed

\author{
Jong Hwa Jun' \\ Wern-Joo Sohn² \\ Youngkyun Lee ${ }^{2}$ \\ Jae-Young Kim²
}

'Department of Ophthalmology, School of Medicine, Dongsan Medical Center, Keimyung University, ${ }^{2}$ Department of Oral Biochemistry, School of Dentistry, IHBR, Kyungpook National University, Daegu,

South Korea
Correspondence: Jong Hwa Jun Department of Ophthalmology, School of Medicine, Dongsan Medical Center, Keimyung University, \#56 Dalseong-ro, Jung-Gu, Daegu 700-7I2, South Korea

$\mathrm{Tel}+82532507708$

Fax +82532507705

Email junjonghwa@gmail.com
Abstract: The molecular and cellular effects of anti-vascular endothelial growth factor monoclonal antibody (bevacizumab) on lens epithelial cells (LECs) were examined using both an immortalized human lens epithelial cell line and a porcine capsular bag model. After treatment with various concentrations of bevacizumab, cell viability and proliferation patterns were evaluated using the water-soluble tetrazolium salt assay and 5-bromo-2'-deoxyuridine enzyme-linked immunosorbent assay, respectively. The scratch assay and Western blot analysis were employed to validate the cell migration pattern and altered expression levels of signaling molecules related to the epithelial-mesenchymal transition (EMT). Application of bevacizumab induced a range of altered cellular events in a concentration-dependent manner. A $0.1-2 \mathrm{mg} / \mathrm{mL}$ concentration demonstrated dose-dependent increase in proliferation and viability of LECs. However, $4 \mathrm{mg} / \mathrm{mL}$ decreased cell proliferation and viability. Cell migrations displayed dosedependent retardation from $0.1 \mathrm{mg} / \mathrm{mL}$ bevacizumab treatment. Transforming growth factor- $\beta 2$ expression was markedly increased in a dose-dependent manner, and $\alpha$-smooth muscle actin, matrix metalloproteinase-9, and vimentin expression levels showed dose-dependent changes in a B3 cell line. Microscopic observation of porcine capsular bag revealed changes in cellular morphology and a decline in cell density compared to the control after $2 \mathrm{mg} / \mathrm{mL}$ treatment. The central aspect of posterior capsule showed delayed confluence, and the factors related to EMT revealed similar expression patterns to those identified in the cell line. Based on these results, bevacizumab modulates the proliferation and viability of LECs and induces morphological alterations through the modulation of expression patterns of specific factors related to the EMT.

Keywords: avastin, bevacizumab, lens epithelial cell, transforming growth factor, vascular endothelial growth factor

\section{Introduction}

The mammalian lens becomes an avascular tissue during the postnatal period after regression of fetal lens vasculatures, which drives oxygen deprivation in the postnatal lens tissues. ${ }^{1}$ Lenticular cells invoke cytoprotective mechanisms including hypoxia-inducible factor and vascular endothelial growth factor (VEGF) signaling pathways. ${ }^{2}$ Accordingly, VEGF expression increases vessel regression in lens epithelial cells (LECs) ${ }^{3}$ when the balance between hypoxia and the compensatory mechanism is tilted to a more hypoxic status even though it is a nonvascular environment. In an in vitro condition, despite an abundant oxygen supply, an increase in the expressions of VEGF and its corresponding receptors was reported. ${ }^{4}$ Addition of VEGF to cultivation media promotes LEC proliferation in both primary and immortalized human cell lines. ${ }^{4}$ Based on these controversial results, we hypothesize that VEGF plays important roles in not only angiogenesis but 
also unknown processes including the proper physiological formation and maintenance of lens epithelia.

Recently, to investigate VEGF signaling transduction in various ocular tissues, an anti-VEGF monoclonal antibody, ranibizumab, was introduced and evaluated for inhibitory properties related to proliferative vitreoretinopathy., In addition, recent studies demonstrated the effects of topical and subconjunctival application of bevacizumab (Avastin; Genentech, South San Francisco, CA, USA), which modulates the wound healing response of the corneal epithelia. ${ }^{7-9}$ Subconjunctival injection of bevacizumab, alkali-burn model, showed that bevacizumab modulated the expressions of transforming growth factor-beta (TGF- $\beta$ ) and $\alpha$-smooth muscle actin ( $\alpha$-SMA). ${ }^{9}$

Bevacizumab (MW: $149 \mathrm{kDa})^{10}$ is able to penetrate and affect LECs, since the permeable cutoff of the naïve lens capsule is $166 \mathrm{kDa} .{ }^{11,12}$ Moreover, cataract extraction breaks the normal anteroposterior barrier function and induces direct contact between aqueous fluid and intravitreally injected substances to LECs by altered aqueous circulation. Combining both cataract extraction and intravitreal bevacizumab injection treatments could directly affect the physiology of LECs.

This study evaluated the possible effects of bevacizumab on proliferation, cell viability, and wound healing processes with Epithelial mesenchymal transition (EMT) signaling. We evaluated the effects of treatment with various concentrations of bevacizumab on LECs with a human immortalized cell line as well as a porcine in vitro capsular bag model.

\section{Materials and methods HLE-B3 cell line and cultivation}

B3 cells, a human lens epithelial cell line immortalized by the SV-40 virus, were purchased from American Type Culture Collection (Manassas, VA, USA). No ethical approval was sought or required for experiments involving commercially purchased cell lines, as per guidelines of the Keimyung University human subjects protection program/ethical review board. Cells were maintained in minimal essential medium (MEM; Welgene, Daegu, Korea) supplemented with $10 \%$ (v/v) fetal bovine serum (FBS; Thermo Fisher Scientific, Waltham, MA, USA) and 1\% (v/v) penicillin/streptomycin (Thermo Fisher Scientific) in a humidified $37^{\circ} \mathrm{C}, 5 \% \mathrm{CO}_{2}$ incubator.

\section{WST-8 cell viability assay after treatment with bevacizumab}

In previous studies, ${ }^{10,13,14}$ the pharmacokinetics and distribution of bevacizumab after intravitreal injection of $1.25 \mathrm{mg} / 0.05 \mathrm{~mL}$ in both animal and human models showed maximum concentrations at 1-3 days with half-lives of 4-6.5 days in animals. We evaluated the cell viability 72 hours after treatment with $0.1 \mathrm{mg} / \mathrm{mL}, 0.5 \mathrm{mg} / \mathrm{mL}, 1 \mathrm{mg} / \mathrm{mL}$, $2 \mathrm{mg} / \mathrm{mL}$, or $4 \mathrm{mg} / \mathrm{mL}$ bevacizumab and phosphate-buffered saline (PBS) as a control. We detected dehydrogenase activity in cell culture medium with cell counting kit-8 (Dojindo Molecular Technologies, Rockville, MD, USA). B3 cells were plated in a 48 -well culture plate in a $10 \%$ serum supplemented medium. After culturing for 24 hours, the medium was replaced by a serum-free medium, and B3 cells were subjected to an initial 24-hour starvation period. Cells were cultured for a subsequent 72 hours in media containing $0.1 \mathrm{mg} / \mathrm{mL}$, $0.5 \mathrm{mg} / \mathrm{mL}, 1 \mathrm{mg} / \mathrm{mL}, 2 \mathrm{mg} / \mathrm{mL}$, or $4 \mathrm{mg} / \mathrm{mL}$ bevacizumab supplemented with $10 \%$ FBS. At 72 hours, the medium was refreshed, and 10\% (v/v) WST-8 was added. After 4 hours incubation, the yellow formazan dye was colorimetrically detected with an enzyme-linked immunosorbent assay (ELISA) reader (Multiskan ${ }^{\mathrm{TM}}$ GO Microplate Spectrophotometer; Thermo Fisher Scientific). Optical density values were converted to relative cell viability compared to control groups. Each experiment was performed at least ten times.

\section{5-bromo-2'-deoxyuridine proliferation assay after treatment with bevacizumab}

B3 cells were seeded in 48-well plates and cultivated for 24 hours to $50 \%-60 \%$ confluence in MEM supplemented with $10 \%$ FBS. On reaching the desired level of confluence, cultivation medium was replaced with serum-free MEM, and cells were incubated for 24 hours. After 24 hours, the medium was changed to MEM containing $0.1 \mathrm{mg} / \mathrm{mL}$, $0.5 \mathrm{mg} / \mathrm{mL}, 1 \mathrm{mg} / \mathrm{mL}, 2 \mathrm{mg} / \mathrm{mL}$, or $4 \mathrm{mg} / \mathrm{mL}$ bevacizumab supplemented with $10 \%$ FBS. Control cells were incubated with growth medium containing PBS. After 72 hours, 5-bromo-2'-deoxyuridine (BrdU; Hoffman-La Roche Ltd, Basel, Switzerland) was added to the medium and reincubated for 1.5-2 hours. Cells were washed with PBS three times and denatured. Incorporated BrdU in LECs was detected by anti-BrdU-peroxidase conjugated antibody, and photometric detections were performed using BrdU ELISA kit (Hoffman-La Roche Ltd) and ELISA reader. Each experiment was performed at least ten times.

\section{Scratch assay for LEC migration after treatment with bevacizumab}

B3 cells were cultured in MEM supplemented with $10 \%$ FBS and seeded into 48-well plates. When the LECs reached $90 \%-95 \%$ confluence as a monolayer, the medium was changed to serum-free medium, and the cells were incubated for 24 hours. Linear scratch wounds across the centers of the 
wells were created by $200-\mu \mathrm{L}$ micropipette tip. The medium was replaced with serum-free medium containing $0.1 \mathrm{mg} / \mathrm{mL}$, $0.5 \mathrm{mg} / \mathrm{mL}, 1 \mathrm{mg} / \mathrm{mL}$, or $2 \mathrm{mg} / \mathrm{mL}$ bevacizumab and PBS as a control treatment. After 72-hour incubation, images were taken with a phase contrast microscope (Leica DM IL LED; Leica Microsystems, Wetzlar, Germany). The number of migratory cells from the scratch wound margin to the cell free surface was counted using Image J (NIH, Bethesda, MD, USA). Each experiment was repeated three times.

\section{Porcine lens capsular bag preparation}

Porcine eyeballs were obtained from a local abattoir within 4 hours postmortem. The whole lenses were separated. Low-melting point (LMP) agarose gel powder ( $0.2 \mathrm{~g}$, agarose, LMP, analytical grade, V2111; Promega Corporation, Fitchburg, WI, USA) was dissolved and then boiled and cooled to $37^{\circ} \mathrm{C}$. The lenses were positioned on the embedding molds (Peel-A-Way ${ }^{\circledR}$; Ted Pella Inc., Redding, CA, USA), and gel solution was poured. Lenses were cultured in the medium, and sham cataract surgery was performed as previously described. ${ }^{15}$ Capsular bags were cultured in Dulbecco's Modified Eagle's Medium (DMEM; Thermo Fisher Scientific) supplemented with $20 \%$ FBS and $1 \%$ penicillin/ streptomycin in a humidified, $37^{\circ} \mathrm{C}, 5 \% \mathrm{CO}_{2}$ incubator. After 12 hours, the medium was replenished with $10 \%$ FBS/ DMEM. The medium was changed every 48 hours.

\section{Western blot analysis on both cell and capsular bag cultivations}

Lysates of specimens were denatured in sodium dodecyl sulfate sample loading buffer. Proteins were separated by sodium dodecyl sulfate polyacrylamide gel electrophoresis and transferred to a nitrocellulose membrane. Membranes were blocked for 1 hour before incubation with anti-TGF- $\beta 2$ (SC-90; Santa Cruz Biotechnology Inc., Dallas, TX, USA), $\alpha$-SMA (ab15734; Abcam, Cambridge, UK), vimentin (LF-MA0263; AbFrontier, Seoul, South Korea), proliferating cell nuclear antigen (PCNA, IHC-00012; Bethyl Laboratories Inc., Montgomery, TX, USA), matrix metalloproteinase-9 (MMP-9, SC-6841; Santa Cruz Biotechnology Inc.), or glyceraldehyde-3-phosphate dehydrogenase (SC-20357; Santa Cruz Biotechnology Inc.) primary antibody. The immunoblot was detected by enhanced chemiluminescence using an image analyzer (Fusion FX; Vilber Lourmet, France).

\section{Statistical analysis}

To compare the effects of various concentrations of bevacizumab treatment, a one-way analysis of variance test was performed, and Tukey's honest significant difference (HSD) post hoc test was employed for comparisons between concentration groups using SPSS 12.0 (SPSS Inc., Chicago, IL, USA).

\section{Results \\ Cell viability assay for evaluation of bevacizumab treatment on HLE-B3}

Groups treated with $1 \mathrm{mg} / \mathrm{mL}$ or $2 \mathrm{mg} / \mathrm{mL}$ showed greater cell viability than control groups $(P=0.039$ and $P=0.009$, respectively, Tukey's HSD test). Cell viability in this range of bevacizumab concentrations was determined to gradually increase in a dose-dependent manner with statistically significant correlation ( $r=0.609, P<0.000)$. However, $4 \mathrm{mg} / \mathrm{mL}$ treatment group displayed obvious cytotoxic effects on LECs compared with the lower concentration treatment groups $(P=0.04, P=0.007$, and $P=0.001$, respectively, Tukey's HSD test; Figure $1 \mathrm{~A})$.

\section{BrdU ELISA for evaluation of bevacizumab effects on cell proliferation}

The $4 \mathrm{mg} / \mathrm{mL}$ treatment showed a distinct decrease in proliferation levels compared with the lower concentration treatments including $0.5 \mathrm{mg} / \mathrm{mL}, 1 \mathrm{mg} / \mathrm{mL}$, and $2 \mathrm{mg} / \mathrm{mL}$ ( $P=0.006, P=0.004$, and $P=0.002$, respectively, Tukey's HSD test). These lower concentration groups exhibited increased proliferation properties in a dose-dependent manner with statistically significant correlation $(r=0.603, P=0.001)$. Moreover, treatment with lower concentrations resulted in higher proliferation than the control group $(P=0.047, P=0.029$, and $P=0.018$, respectively, Tukey's HSD; Figure 1B). Cell density of B3 cells after treatment with various concentrations of bevacizumab showed a similar pattern (Figure 1C).

\section{Altered motility pattern of LEC after bevacizumab treatment}

To evaluate the effects of bevacizumab on LEC motility, we evaluated the LEC migration from the edge of a linear scratch wound after treatment with various concentrations. At 72-hour incubation after administration of bevacizumab $(0.1 \mathrm{mg} / \mathrm{mL}, 0.5 \mathrm{mg} / \mathrm{mL}, 1 \mathrm{mg} / \mathrm{mL}$, or $2 \mathrm{mg} / \mathrm{mL})$, LEC migrations were reduced in a dose-dependent manner ( $P=0.031$, $P=0.004, P=0.001$, and $P=0.000$, respectively, Tukey's HSD). Most notably, the $2 \mathrm{mg} / \mathrm{mL}$ treatment group showed a significant reduction of cell migration when compared with the $0.1 \mathrm{mg} / \mathrm{mL}$ treatment group (Figure 1D and E).

Decreased central posterior capsular cell confluence in the lens capsular bag model In the capsular bag model, LEC confluence on the posterior aspect of the capsular bag would be informative, especially with respect to Posterior capsule opacification (PCO) 
A

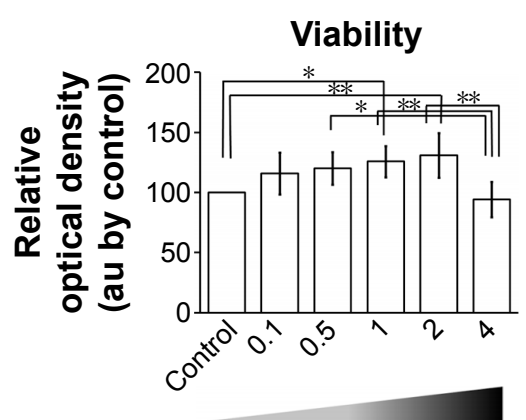

Bevacizumab concentration $(\mathrm{mg} / \mathrm{mL})$

C
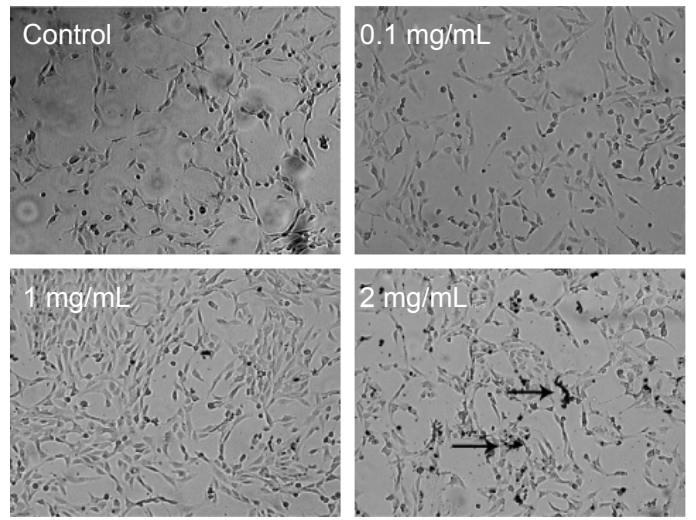

D

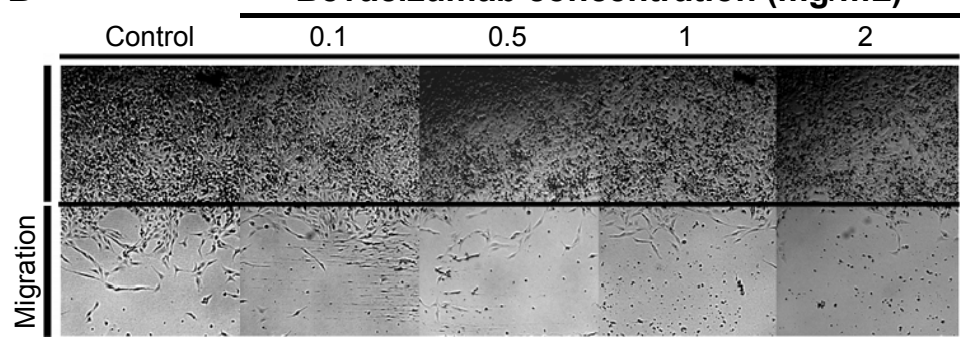

B

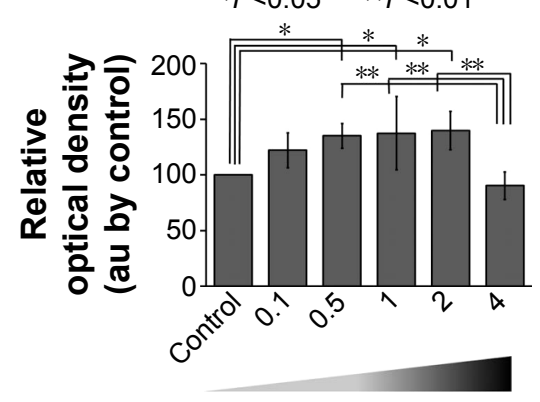

Bevacizumab concentration $(\mathrm{mg} / \mathrm{mL})$

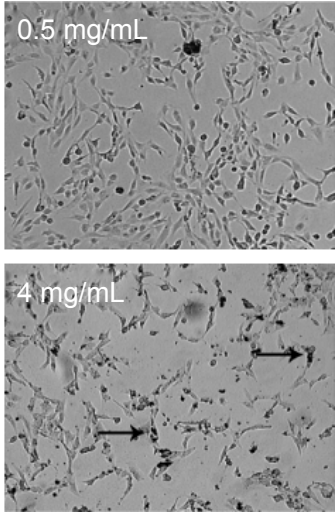

E

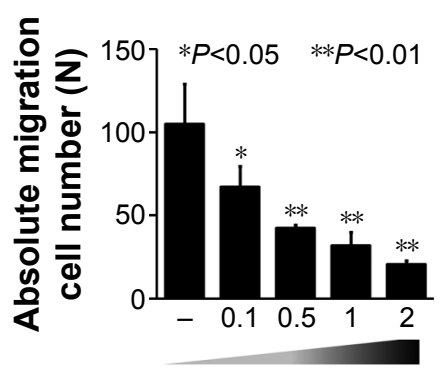

Bevacizumab concentration $(\mathrm{mg} / \mathrm{mL})$

Figure I Effects of bevacizumab on proliferation and migration of LECs.

Notes: (A) Cell viability assay using the cell counting kit-8 after treatment with various bevacizumab concentrations. In LECs, treatment with $4 \mathrm{mg} / \mathrm{mL}$ bevacizumab showed a significant decrease in cell viability compared with control, $0.1 \mathrm{mg} / \mathrm{mL}, 0.5 \mathrm{mg} / \mathrm{mL}, \mathrm{I} \mathrm{mg} / \mathrm{mL}$, and $2 \mathrm{mg} / \mathrm{mL}$ bevacizumab treatment after $72-$ hour incubation. Up to $2 \mathrm{mg} / \mathrm{mL}$ bevacizumab, cell viability increased in a dose-dependent manner. (B) BrdU enzyme-linked immunosorbent proliferation assay after treatment with various bevacizumab concentrations. As in the cell viability assay, cell proliferation increased with bevacizumab dose up to $2 \mathrm{mg} / \mathrm{mL}$ concentration but declined abruptly at $4 \mathrm{mg} / \mathrm{mL}$ concentration. (C) Microscopic images after application of various bevacizumab concentrations. In human lens epithelial B3 cells, treatment with $4 \mathrm{mg} / \mathrm{mL}$ bevacizumab showed a significant decline in cell density compared with control, $0.1 \mathrm{mg} / \mathrm{mL}, 0.5 \mathrm{mg} / \mathrm{mL}, I \mathrm{mg} / \mathrm{mL}$, and $2 \mathrm{mg} / \mathrm{mL}$ bevacizumab treatment after 72 -hour incubation. The densities of viable attached cells increased in a dose-dependent manner, but $4 \mathrm{mg} / \mathrm{mL}$ bevacizumab treatment resulted in an abrupt decrement in cell density. Interestingly, treatment with I mg/mL or $2 \mathrm{mg} / \mathrm{mL}$ bevacizumab showed a significant number of detached nonviable cells in the culture medium, but the attached cell density was higher than for cells treated with lower concentrations $(0 \mathrm{mg} / \mathrm{mL}$, $0.1 \mathrm{mg} / \mathrm{mL}$, and $0.5 \mathrm{mg} / \mathrm{mL}$ ). These results agreed with the BrdU proliferation and cell viability assays. Arrowheads indicate shrunken cells (magnification, $40 \times$ ). (D and E) Scratch assay for cell migration after treatment with various bevacizumab concentrations and 72-hour treatment under cell starvation conditions. Microscopic images show that LEC migrations from the scratch edges decreased in a dose-dependent manner. Migration of LECs statistically significantly decreased at the lowest dose of bevacizumab (0.I $\mathrm{mg} / \mathrm{mL}$; $P<0.05$, Tukey's HSD post hoc test, by oneway-ANOVA). The inhibitory effect on migration was apparent over $0.5 \mathrm{mg} / \mathrm{mL}$ bevacizumab compared with control $(P<0.0 \mathrm{I}$, Tukey's HSD post hoc test, by oneway-ANOVA). Magnification, $\times 40$. Results are in response to a one way analysis of variance (ANOVA). $* P<0.05, * * P<0.01$.

Abbreviations: LECs, lens epithelial cells; BrdU, 5-bromo-2'-deoxyuridine; HSD, honest significant difference; ANOVA, analysis of variance.

progression. For each capsular bag specimen, cultivation medium was changed to $5 \% \mathrm{FBS} / \mathrm{DMEM}$ containing $0 \mathrm{mg} / \mathrm{mL}$, $1 \mathrm{mg} / \mathrm{mL}$, or $2 \mathrm{mg} / \mathrm{mL}$ bevacizumab, and confluence patterns of LECs were observed under the anterior capsulorrhexis margin. For 48 hours, microscopic images were captured at 12-hour intervals, and the LEC confluences were analyzed in Image J. The coverage of the posterior capsule was decreased at $2 \mathrm{mg} / \mathrm{mL}$ after 12 hours $(P<0.05)$. Controls showed significantly earlier cell coverage than the $1 \mathrm{mg} / \mathrm{mL}$ and $2 \mathrm{mg} / \mathrm{mL}$ treatment groups after 36 hours $(P<0.01$, Tukey's HSD 
post hoc test) and 48 hours $(P<0.05$ and $P<0.01$ in $1 \mathrm{mg} / \mathrm{mL}$ and $2 \mathrm{mg} / \mathrm{mL}$, respectively, Tukey's HSD post hoc test; Figure 2).

\section{Cell morphology and proliferation of LECs on the anterior capsule}

Phase-contrast microscopy of the capsular bags revealed decrease in proliferation in the anterior capsule after 120 hours. In addition, when LECs achieved confluence on the anterior capsule, the cellular density of anterior capsular LECs in lower magnification indicated bleb formation (Figure 3A). Under higher resolution, it became apparent that the morphology of LECs was altered to an elongated shape, similar to that observed in TGF- $\beta$-related cellular changes reported in a previous study. ${ }^{16}$

\section{Western blot analysis of HLE-B3 cells and the capsular bag model}

To evaluate the effects of bevacizumab on proliferation and EMT, Western blot analysis using EMT markers ( $\alpha$-SMA, MMP-9, and vimentin), a proliferation marker (PCNA), and TGF- $\beta 2$ was performed in both B3 cells and porcine lens capsular bags. Bevacizumab treatment induced a marked increase in TGF- $\beta 2$ expression in a dose-dependent manner. Vimentin expression levels also increased with dose, but MMP-9 expression levels decreased with bevacizumab treatment over $1 \mathrm{mg} / \mathrm{mL}$. Expression levels of PCNA and $\alpha$-SMA were highest after treatment with $0.5 \mathrm{mg} / \mathrm{mL}$ bevacizumab in HLE-B3 cells (Figure 3B). In addition, PCNA and $\alpha$-SMA revealed similar expression patterns in cultured cells, but the highest expression levels were observed at $1 \mathrm{mg} / \mathrm{mL}$ bevacizumab in the capsular bag model (Figure 3C).

\section{Discussion}

Bevacizumab is a recombinant humanized monoclonal immunoglobulin G1 (IgG1) antibody that binds and inhibits VEGF-A. It was initially approved for the treatment of colorectal cancer, ${ }^{17}$ but in recent years, bevacizumab has become a mainstay treatment for vitreoretinal neovascular diseases. Because of their emerging novel application in ophthalmic departments, recent studies evaluated the effects of anti-VEGF antibodies, bevacizumab and ranibizumab, on pathological vascularized conditions caused by formation of new vessels from preexisting vessels in ocular tissues, especially corneal new vessel formation, pterygial tissues of the conjunctiva ${ }^{18-22}$ and retina, and retinopathy of prematurity. ${ }^{23}$ Interestingly, recent evidence revealed that VEGF-A is involved in lymphangiogenesis, suggesting that anti-VEGF antibodies could also inhibit lymphangiogenesis. ${ }^{24-26}$

Previously, cytotoxicity of bevacizumab on various intraocular tissues was reported. Chalam et $\mathrm{al}^{27}$ demonstrated a lack of cytotoxicity from various doses of bevacizumab on corneal epithelial and fibroblast cells. More recently, $1.5 \mathrm{mg} / \mathrm{mL}$ and $2 \mathrm{mg} / \mathrm{mL}$ doses of bevacizumab exhibited an antiproliferative effect on bovine corneal endothelial cells. ${ }^{28}$ In other reports, cytotoxicity on retinal cells in vivo and in vitro ${ }^{28-30}$ was also evaluated. In these studies, $<2 \mathrm{mg} / \mathrm{mL}$ exhibited no cytotoxic effect. However, the lens could directly contact bevacizumab after intravitreal injection, and there are no data on the effects. In this study, we assessed non-antiangiogenic effects arising from
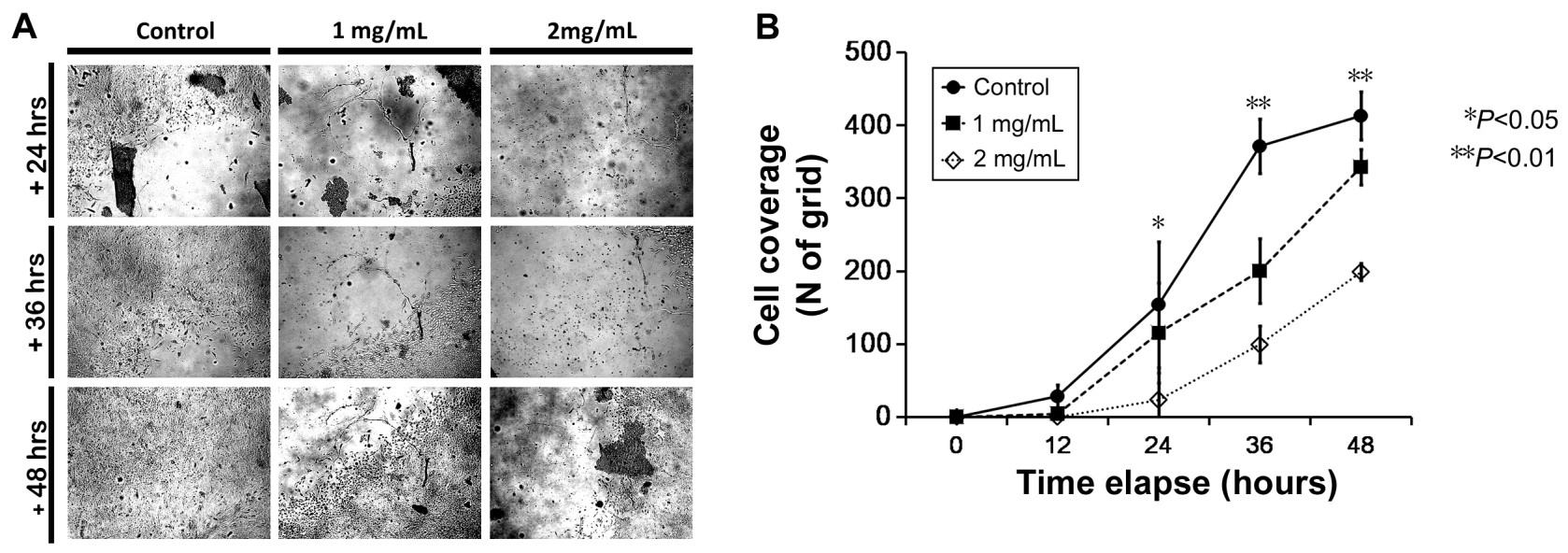

Figure 2 Central confluence of posterior capsule in porcine lenses. (A) Central coverage of posterior capsule decreased in a dose-dependent manner (B) After treatment with various doses of bevacizumab, coverage of the posterior capsule in porcine lenses.

Notes: After treatment with various doses of bevacizumab, coverage of the posterior capsule decreased in the first 12 hours at $2 \mathrm{mg} / \mathrm{mL}$ bevacizumab $(P<0.05$, by one way-ANOVA). In addition, with an increase of incubation time, the control group showed a greater difference in cell coverage than both I $\mathrm{mg} / \mathrm{mL}$ and $2 \mathrm{mg} / \mathrm{mL}$ groups at 36 hours $(P<0.0$ I, Tukey's HSD post hoc test, by oneway-ANOVA) and 48 hours $(P<0.05$ and $P<0.01$ in I mg/mL and $2 \mathrm{mg} / \mathrm{mL}$, respectively, Tukey's HSD post hoc test, by oneway-ANOVA). Data are displayed as mean \pm SD. Magnification, $\times 40$. Results are in response to a one way analysis of variance $(A N O V A)$. $* P<0.05, * * P<0.0$ I.

Abbreviations: HSD, honest significant difference; h, hours; ANOVA, analysis of variance. 
A
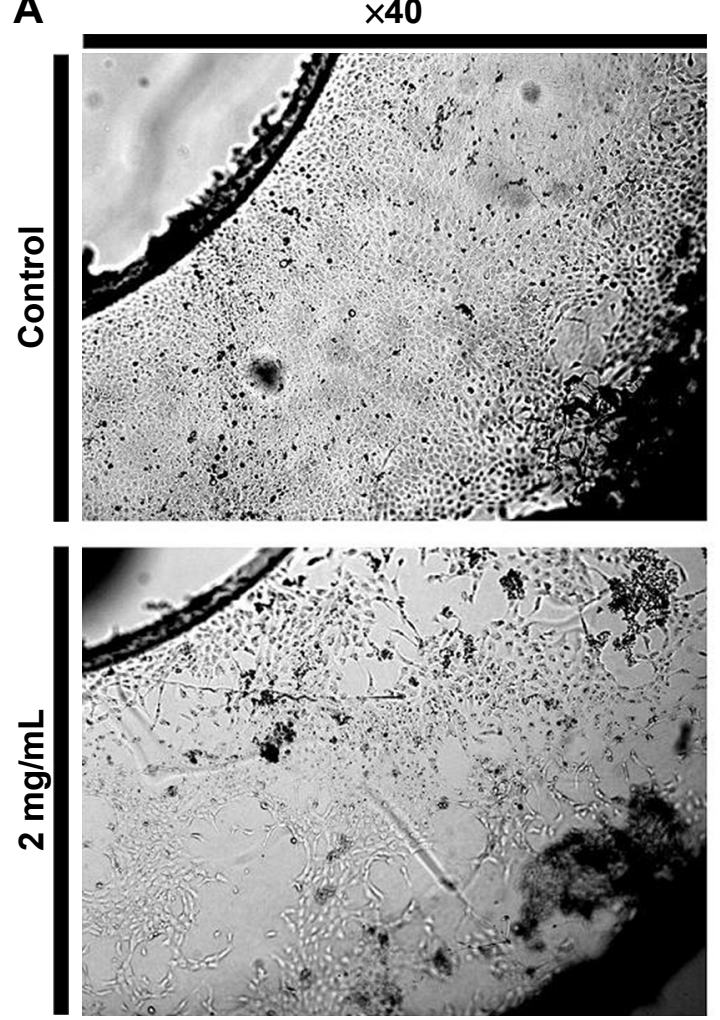

B

\section{Bevacizumab concentration $(\mathrm{mg} / \mathrm{mL})$}

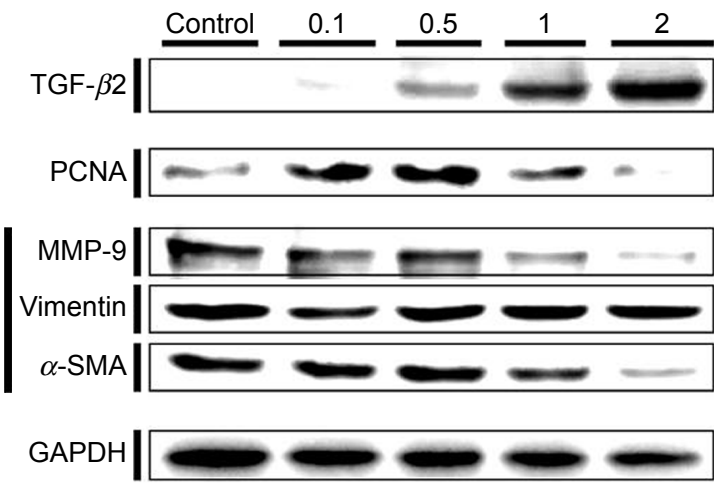

$\times 100$
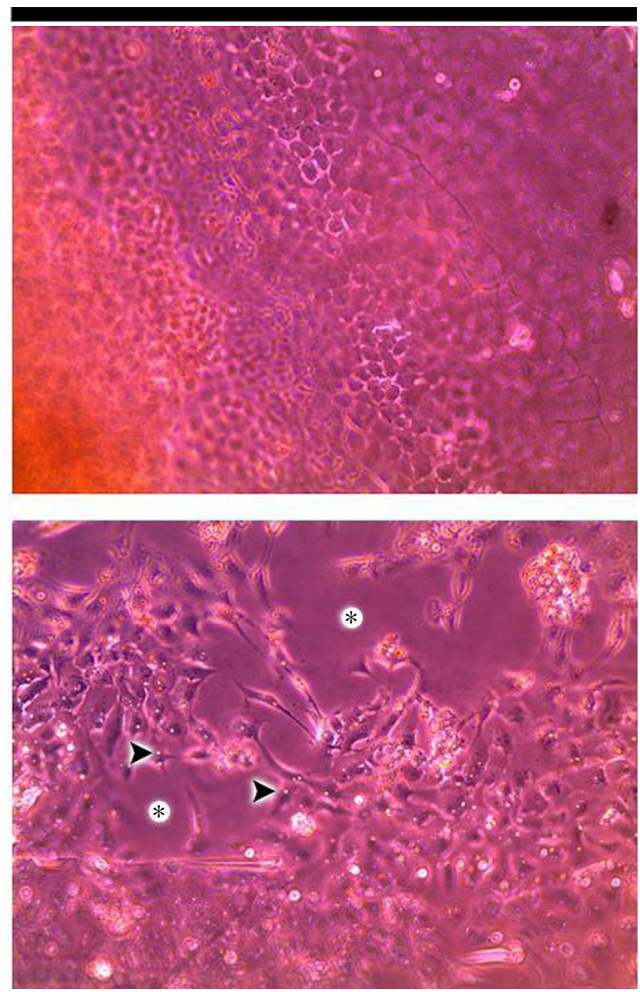

C Bevacizumab concentration $(\mathrm{mg} / \mathrm{mL})$

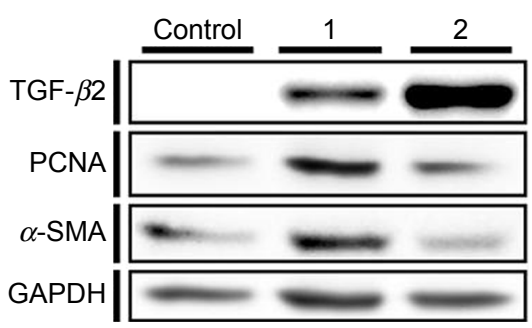

Figure 3 Effects of bevacizumab on cellular morphology and expression of factors related to EMT and proliferation.

Notes: (A) Microscopic morphology of anterior capsular LECs for control and $2 \mathrm{mg} / \mathrm{mL}$ bevacizumab treatment in lens capsular bag after 120 hours cultivation. Capsular bag LECs showed decreased cell density (asterisks) and bleb-like morphological changes after cultivation in $2 \mathrm{mg} / \mathrm{mL}$ bevacizumab (arrowheads). (B and C) Western blot analysis after treatment with various bevacizumab concentrations in cultured cell and porcine lens capsular bags. TGF- $\beta 2$ is markedly increased in a dose-dependent manner in both systems. Western blot analysis of cultured cells revealed increase-peak-decrease patterns in PCNA and $\alpha$-SMA expression around $0.5 \mathrm{mg} / \mathrm{mL}$ concentration. The expression pattern of PCNA is in agreement with results from the cell viability assay by cell counting kit- 8 and the BrdU proliferation assay. Overall, MMP- 9 showed a decrease in expression over I mg/mL treatment, whereas vimentin expression increased in a dose-dependent manner. Similarly, PCNA and $\alpha$-SMA expression levels peaked at I mg/mL bevacizumab in the porcine lens capsular bag model.

Abbreviations: LECs, lens epithelial cells; TGF- $\beta 2$, transforming growth factor- $\beta 2$; PCNA, proliferating cell nuclear antigen; $\alpha$-SMA, $\alpha$-smooth muscle actin; BrdU, 5 -bromo2'-deoxyuridine; MMP-9, matrix metalloproteinase-9; GAPDH, glyceraldehyde-3-phosphate dehydrogenase.

treatment with various concentrations of bevacizumab. A previous animal study reported a relatively high concentration, $>0.5 \mathrm{mg} / \mathrm{mL}, 24$ hours after injection. ${ }^{10}$ However, in an in vivo animal study, the maximum concentration of bevacizumab was measured as $<1 \mathrm{mg} / \mathrm{mL}$. These results could differ from humans, and the status of vitreal liquefaction or vitreous humor circulation could result in localized concentrations $>1 \mathrm{mg} / \mathrm{mL}$. In addition, the conventional dosage is $1.25 \mathrm{mg} / 0.05 \mathrm{~mL}(25 \mathrm{mg} / \mathrm{mL})$, and the concentration could be high during the 24 hours after injection 
because the vitreal cavity is filled with fine gelatinous fibers instead of fluid.

In our experiments, we evaluated the effects of bevacizumab on cell viability, proliferation, migration, and EMT of LECs in both an in vitro immortalized human cell line and porcine lens capsular bags. Cell viability assays showed that $1 \mathrm{mg} / \mathrm{mL}$ and $2 \mathrm{mg} / \mathrm{mL}$ doses resulted in higher LEC viabilities. In addition, cell viability was increased with higher dosages. In fact, statistical correlation analysis identified relatively high correlation. Observation of cells during LEC cultivation showed a similar pattern in cell density after bevacizumab treatment (Figure 1C-I). However, higher doses $(1 \mathrm{mg} / \mathrm{mL}, 2 \mathrm{mg} / \mathrm{mL}$, and $4 \mathrm{mg} / \mathrm{mL})$ resulted in detached cells in culture media, and the proportion of detached cells increased with dosage (data not shown). Based on these results, we hypothesize that bevacizumab treatment promotes the proliferation of LECs and, under $2 \mathrm{mg} / \mathrm{mL}$ treatment, the degree of proliferation exceeds cell death. However, treatment with $4 \mathrm{mg} / \mathrm{mL}$ resulted in decreased cell viability of B3 cells after 72-hour incubation.

On the other hand, LEC migration as measured by the cell scratch assay showed contrary patterns to cell viability and proliferation assay. In previous reports on the corneal wound healing process after treatment, higher concentrations of bevacizumab were found to impede corneal wound healing as shown by an in vivo corneal wound healing and an in vitro wound healing assay. ${ }^{7}$ In this study, we examined a similar decreased migration pattern of LECs as shown in the previous report. ${ }^{7}$ LECs showed a more obvious decrease in migration pattern with treatment $(0.5-2 \mathrm{mg} / \mathrm{mL})$ than corneal epithelia. Although there is no clinical report that intravitreal bevacizumab treatment altered $\mathrm{PCO}$ progression, we hypothesize that bevacizumab affects the migration and modulation of PCO processes in LECs, which is relevant to the conventional dosage of intravitreal injection since intravitreal concentrations reached $0.5 \mathrm{mg} / \mathrm{mL}$ in 72 hours in an in vivo model.

Western blot analysis showed that TGF- $\beta 2$ was markedly elevated in a dose-dependent manner. Especially in LECs, TGF- $\beta 2$ is involved in the EMT process after cataract extraction. As shown in the previous report of the corneal wound healing model, ${ }^{7}$ expression of TGF- $\beta 2$ increased two- to threefold over controls. Recently, several studies reported the effects of the $\mathrm{Fc}$ receptor in bevacizumab. ${ }^{31,32}$ In these previous studies, it was shown to induce a significant elevation in the cytokine milieu, including interleukin- 8 and TGF- $\beta 2$. Furthermore, Chen et al ${ }^{31}$ evaluated the same concentrations of the isotype control IgG1, and bevacizumab showed similar elevations of connective tissue growth factor expression, and Nakao et $\mathrm{al}^{33}$ confirmed localizations of TGF- $\beta$ in vascular endothelial cells of fibrovascular membrane after treatment with bevacizumab. Fc-Fc interactions of bevacizumab or unknown pathway possibly alter the expression of TGF- $\beta 2$ and other related EMT factors. Expression of PCNA was also decreased in $1 \mathrm{mg} / \mathrm{mL}$ and $2 \mathrm{mg} / \mathrm{mL}$ bevacizumab doses in a dose-dependent manner (Figure $3 \mathrm{~B}$ and $\mathrm{C}$ ). This result is in accordance with the standardized result of proliferation, which peaked at $0.5 \mathrm{mg} / \mathrm{mL}$ doses and abruptly decreased with doses $>1 \mathrm{mg} / \mathrm{mL}$. However, $\alpha$-SMA expression was lower in capsular bags treated with $2 \mathrm{mg} / \mathrm{mL}$ bevacizumab than in the control. This result is different from that of the corneal wound healing model..$^{7-9}$ We suggest that this should be considered a consequence of decreased LEC proliferation.

In addition, LEC morphology of $2 \mathrm{mg} / \mathrm{mL}$ treated samples was altered and differed from the control in an in vitro capsular bag (Figure 3A). The cellular density was less than control, and microscopic images showed cell surface blebs and moderate elongations (Figure 3A). As was shown in previous studies, TGF- $\beta 2$ decreases LEC proliferation, and the alteration of cell density observed in our study may result from increased expression of TGF- $\beta 2 .{ }^{16}$ Therefore, this morphological alteration may result from the altered expression of VEGF. In addition, as was examined in a previous study, this morphological alteration of LECs by bevacizumab is similar to that of TGF- $\beta$ treatment. ${ }^{16}$

\section{Conclusion}

Our study demonstrates that bevacizumab changes the proliferation, viability, and migration of LECs at concentrations $<2 \mathrm{mg} / \mathrm{mL}$. In addition, these treatments altered the expression of important factors related to EMT of LECs including dose-dependent elevation of TGF- $\beta 2$ and dose-specific alteration of $\alpha$-SMA and MMP-9 expression. Furthermore, in an in vitro capsular bag model, treatment with $2 \mathrm{mg} / \mathrm{mL}$ bevacizumab showed decreased cell density and morphological changes (bleb formations and LEC elongation).

\section{Acknowledgment}

This work was supported by the National Research Foundation of Korea (NRF) grant funded by the Korea government (Ministry of Science, ICT and Future Planning) (NRF-2015R1C1A1A02037062).

\section{Disclosure}

The authors report no conflicts of interest in this work. 


\section{References}

1. McNulty R, Wang H, Mathias RT, Ortwerth BJ, Truscott RJ, Bassnett S. Regulation of tissue oxygen levels in the mammalian lens. $J$ Physiol. 2004;559(pt 3):883-898.

2. Neelam S, Brooks MM, Cammarata PR. Lenticular cytoprotection. Part 1: the role of hypoxia inducible factors-1alpha and -2alpha and vascular endothelial growth factor in lens epithelial cell survival in hypoxia. Mol Vis. 2013;19:1-15.

3. Shui YB, Wang X, Hu JS, et al. Vascular endothelial growth factor expression and signaling in the lens. Invest Ophthalmol Vis Sci. 2003; 44(9):3911-3919.

4. Saint-Geniez M, Kurihara T, D'Amore PA. Role of cell and matrixbound VEGF isoforms in lens development. Invest Ophthalmol Vis Sci. 2009;50(1):311-321.

5. Pennock S, Kim D, Mukai S, et al. Ranibizumab is a potential prophylaxis for proliferative vitreoretinopathy, a nonangiogenic blinding disease. Am J Pathol. 2013;182(5):1659-1670.

6. Casaroli-Marano RP, Pagan R, Vilaro S. Epithelial-mesenchymal transition in proliferative vitreoretinopathy: intermediate filament protein expression in retinal pigment epithelial cells. Invest Ophthalmol Vis Sci. 1999;40(9):2062-2072.

7. Kim TI, Chung JL, Hong JP, Min K, Seo KY, Kim EK. Bevacizumab application delays epithelial healing in rabbit cornea. Invest Ophthalmol Vis Sci. 2009;50(10):4653-4659.

8. Kim EC, Ryu HW, Lee HJ, Kim MS. Bevacizumab eye drops delay corneal epithelial wound healing and increase the stromal response to epithelial injury in rats. Clin Experiment Ophthalmol. 2013;41(7):694-701.

9. Lee SH, Leem HS, Jeong SM, Lee K. Bevacizumab accelerates corneal wound healing by inhibiting TGF-beta2 expression in alkali-burned mouse cornea. BMB Rep. 2009;42(12):800-805.

10. Sinapis CI, Routsias JG, Sinapis AI, et al. Pharmacokinetics of intravitreal bevacizumab $\left(\right.$ Avastin $^{\circledR}$ ) in rabbits. Clin Ophthalmol. 2011; 5:697-704.

11. Kastner C, Lobler M, Reske T, Sternberg K, Guthoff R, Schmitz KP. Determination of human anterior lens capsule permeability for fluorescent model substances and after-cataract preventive drugs. Biomed Eng. 2012;57:561-563.

12. Kastner C, Lobler M, Sternberg K, et al. Permeability of the anterior lens capsule for large molecules and small drugs. Curr Eye Res. 2013;38(10): 1057-1063.

13. Bakri SJ, Snyder MR, Reid JM, Pulido JS, Singh RJ. Pharmacokinetics of intravitreal bevacizumab (Avastin). Ophthalmology. 2007;114(5): $855-859$.

14. Nomoto H, Shiraga F, Kuno N, et al. Pharmacokinetics of bevacizumab after topical, subconjunctival, and intravitreal administration in rabbits. Invest Ophthalmol Vis Sci. 2009;50(10):4807-4813.

15. Jun JH, Sohn WJ, Lee Y, Chang SD, Kim JY. Experimental lens capsular bag model for posterior capsule opacification. Cell Tissue Res. 2014; 357(1):101-108.

16. Symonds JG, Lovicu FJ, Chamberlain CG. Posterior capsule opacification-like changes in rat lens explants cultured with TGFbeta and FGF: effects of cell coverage and regional differences. Exp Eye Res. 2006; 82(4):693-699.

17. Ferrara N, Hillan KJ, Novotny W. Bevacizumab (Avastin), a humanized anti-VEGF monoclonal antibody for cancer therapy. Biochem Biophys Res Commun. 2005;333(2):328-335.

Clinical Ophthalmology

\section{Publish your work in this journal}

Clinical Ophthalmology is an international, peer-reviewed journal covering all subspecialties within ophthalmology. Key topics include: Optometry; Visual science; Pharmacology and drug therapy in eye diseases; Basic Sciences; Primary and Secondary eye care; Patient Safety and Quality of Care Improvements. This journal is indexed on Submit your manuscript here: http://www.dovepress.com/clinical-ophthalmology-journal
18. DeStafeno JJ, Kim T. Topical bevacizumab therapy for corneal neovascularization. Arch Ophthalmol. 2007;125(6):834-836.

19. Kim SW, Ha BJ, Kim EK, Tchah H, Kim TI. The effect of topical bevacizumab on corneal neovascularization. Ophthalmology. 2008; 115(6):e33-e38.

20. Nava-Castaneda A, Olvera-Morales O, Ramos-Castellon C, GarnicaHayashi L, Garfias Y. Randomized controlled trial of conjunctival autografting combined with subconjunctival bevacizumab for primary pterygium treatment: one year follow-up. Clin Experiment Ophthalmol. 2014;42(3):235-241.

21. Hosseini H, Nejabat M, Mehryar M, Yazdchi T, Sedaghat A, Noori F. Bevacizumab inhibits corneal neovascularization in an alkali burn induced model of corneal angiogenesis. Clin Experiment Ophthalmol. 2007; 35(8):745-748.

22. Sarac O, Demirel S, Oltulu R. Efficacy of intralesional bevacizumab administration in primary pterygium: a quantitative analysis. Eye Contact Lens. 2014;40(1):46-50.

23. Kusaka S, Shima C, Wada K, et al. Efficacy of intravitreal injection of bevacizumab for severe retinopathy of prematurity: a pilot study. Br J Ophthalmol. 2008;92(11):1450-1455.

24. Dastjerdi MH, Saban DR, Okanobo A, et al. Effects of topical and subconjunctival bevacizumab in high-risk corneal transplant survival. Invest Ophthalmol Vis Sci. 2010;51(5):2411-2417.

25. Cho KJ, Choi JS, Choi MY, Joo CK. Effects of subconjunctival ranibizumab in a presensitized rat model of corneal graft. Exp Eye Res. 2013;107:74-79.

26. Cursiefen C, Cao J, Chen L, et al. Inhibition of hemangiogenesis and lymphangiogenesis after normal-risk corneal transplantation by neutralizing VEGF promotes graft survival. Invest Ophthalmol Vis Sci. 2004; 45(8):2666-2673.

27. Chalam KV, Agarwal S, Brar VS, Murthy RK, Sharma RK. Evaluation of cytotoxic effects of bevacizumab on human corneal cells. Cornea. 2009; 28(3):328-333.

28. Rusovici R, Sakhalkar M, Chalam KV. Evaluation of cytotoxicity of bevacizumab on VEGF-enriched corneal endothelial cells. Mol Vis. 2011; 17:3339-3346.

29. Iandiev I, Francke M, Makarov F, et al. Effects of intravitreal bevacizumab (Avastin) on the porcine retina. Graefes Arch Clin Exp Ophthalmol. 2011;249(12):1821-1829.

30. Zayit-Soudry S, Zemel E, Barak A, Perlman I, Loewenstein A. Safety of intravitreal bevacizumab in the developing rabbit retina. Retina. 2011;31(9):1885-1895.

31. Chen CL, Liang CM, Chen YH, Tai MC, Lu DW, Chen JT. Bevacizumab modulates epithelial-to-mesenchymal transition in the retinal pigment epithelial cells via connective tissue growth factor up-regulation. Acta Ophthalmol. 2012;90(5):e389-e398.

32. Forooghian F, Kertes PJ, Eng KT, Agron E, Chew EY. Alterations in the intraocular cytokine milieu after intravitreal bevacizumab. Invest Ophthalmol Vis Sci. 2010;51(5):2388-2392.

33. Nakao S, Ishikawa $\mathrm{K}$, Yoshida S, et al. Altered vascular microenvironment by bevacizumab in diabetic fibrovascular membrane. Retina. 2013;33(5):957-963.
PubMed Central and CAS, and is the official journal of The Society of Clinical Ophthalmology (SCO). The manuscript management system is completely online and includes a very quick and fair peer-review system, which is all easy to use. Visit http://www.dovepress.com/ testimonials.php to read real quotes from published authors. 